\title{
Influences of land reclamation on soil bacterial communities of abandoned salt pans in the Yellow River Delta
}

\author{
Yihao Zhu ${ }^{1}$, Xiliang Song ${ }^{1}$, Xiaoli Liu ${ }^{2}$, Weifeng Chen ${ }^{1}$, Xuchang Niu ${ }^{1}$, and Weizhi Zhou ${ }^{3}$ \\ ${ }^{1}$ Shandong Agricultural University \\ ${ }^{2}$ Shandong Provincial Land Space and Ecological Restoration Center \\ ${ }^{3}$ Shandong University
}

September 24, 2021

\begin{abstract}
Reclamation has been widely accepted to restore abandoned lands. Most studies focused on the improvement of land reclamation in soil nutrients and microbial activities. However, the effects of reclamation time on bacterial communities of abandoned salt pans are still unclear. The object of this study is to: i) assess the successional change of soil physicochemical properties and bacterial communities in reclaimed abandoned salt pans with different reclamation histories, and ii) figure out the main limit factors on the improvement of soil quality in reclaimed abandoned salt pans. The soils in a farmland (RTBL) and six abandoned salt pans with 1 year (RT1), 2 years (RT2), 3 years (RT3), 4 years (RT4), 8 years (RT8), and 9 years (RT9) of reclamation were sampled to investigate the temporal variation of soil properties, heavy metal content, bacterial community composition, and diversity. Results showed that the soil bulk density (BD), total dissolved salt (SS), median particle size (MMAD) decreased with the increase of reclamation time, while soil nutrient (soil organic matter, total nitrogen, available phosphorus, available potassium) showed an opposite trend. The bacterial $\alpha$-diversity increased first, then decrease. Land reclamation enhanced the relative abundances of Acidobacteria, Chloroflexi, and Actinobacteria but reduced the relative abundances of Proteobacteria, Gemmatimonadetes, and Bacteroidetes. Compared with RTBL, the soil nutrients and bacterial community structure in RT1, RT2, RT3, and RT4 showed a significant difference.Therefore, reclamation time is a vital driving force for restoring soil physicochemical properties and bacterial communities in abandoned
\end{abstract}

\section{Hosted file}

Paper.doc available at https://authorea.com/users/435321/articles/538425-influences-of-landreclamation-on-soil-bacterial-communities-of-abandoned-salt-pans-in-the-yellow-riverdelta

\section{Hosted file}

Acknowledgements.docx available at https://authorea.com/users/435321/articles/538425influences-of-land-reclamation-on-soil-bacterial-communities-of-abandoned-salt-pansin-the-yellow-river-delta

\section{Hosted file}

CRediT authorship contribution statement.docx available at https://authorea.com/users/ 435321/articles/538425-influences-of-land-reclamation-on-soil-bacterial-communitiesof-abandoned-salt-pans-in-the-yellow-river-delta

\section{Hosted file}


Additional Information.docx available at https://authorea.com/users/435321/articles/538425influences-of-land-reclamation-on-soil-bacterial-communities-of-abandoned-salt-pans-inthe-yellow-river-delta

\section{Hosted file}

References.docx available at https://authorea.com/users/435321/articles/538425-influencesof-land-reclamation-on-soil-bacterial-communities-of-abandoned-salt-pans-in-the-yellowriver-delta

\section{Hosted file}

Figure.doc available at https://authorea.com/users/435321/articles/538425-influences-ofland-reclamation-on-soil-bacterial-communities-of-abandoned-salt-pans-in-the-yellowriver-delta

\section{Hosted file}

Table.doc available at https://authorea.com/users/435321/articles/538425-influences-of-landreclamation-on-soil-bacterial-communities-of-abandoned-salt-pans-in-the-yellow-riverdelta

\section{Hosted file}

Graphical Abstract.doc available at https://authorea.com/users/435321/articles/538425influences-of-land-reclamation-on-soil-bacterial-communities-of-abandoned-salt-pans-inthe-yellow-river-delta 